\title{
Infectious diseases among travellers and migrants in Europe, EuroTravNet 2010
}

P Gautret ${ }^{1}$, J P Cramer ${ }^{2}$, V Field 3 , E Caumes 4 , M Jensenius 5 , E Gkrania-Klotsas ${ }^{6}$, P J de Vries ${ }^{7}$, M P Grobusch ${ }^{7}$, R Lopez-Velez ${ }^{8}$,

F Castelli9, P Schlagenhauf ${ }^{10}$, H Hervius Askling $^{11}$, F von Sonnenburg ${ }^{12}$, D G Lalloo ${ }^{13}$, L Loutan ${ }^{14}$, C Rapp $^{15}$, F Basto ${ }^{16}$,

F Santos 0'Connor ${ }^{17}$, L Weld ${ }^{18}$, P Parola (philippe.parola@univ-amu.fr) ${ }^{1}$, for the EuroTravNet Network ${ }^{19}$

1. University Hospital Institute for Infectious and Tropical Diseases, Marseille, France

2. University Medical Center Hamburg-Eppendorf, Department of Tropical Medicine and Infectious Diseases, Bernhard Nocht Clinic, Hamburg, Germany

3. InterHealth and National Travel Health Network and Centre (NaTHNaC), London, United Kingdom

4. Service des Maladies Infectieuses et Tropicales (Department of Infectious and Tropical Diseases), Hôpital Pitié-Salpétrière, Paris, France

5. Department of Infectious Diseases, Oslo University Hospital, Oslo, Norway

6. Department of Infectious Diseases, Addenbrooke's Hospital, Cambridge, United Kingdom

7. Center for Tropical Medicine and Travel Medicine, Department of Infectious Diseases, Academic Medical Center, Amsterdam, the Netherlands

8. Tropical Medicine and Clinical Parasitology, Infectious Diseases Department, Ramón y Cajal Hospital, Madrid, Spain

9. University Division of Infectious and Tropical Diseases, University of Brescia and Brescia Spedali Civili General Hospital, Brescia, Italy

10. Centre for Travel Medicine, University of Zürich, Zürich, Switzerland

11. Department of Medicine/Solna, Unit for Infectious Diseases, Karolinska Institute, Stockholm, Sweden

12. Department of Infectious Diseases and Tropical Medicine, Ludwig-Maximilian's University of Munich, Munich, Germany

13. Liverpool School of Tropical Medicine, Liverpool, United Kingdom

14. Division of International and Humanitarian Health, Geneva University Hospitals, Geneva, Switzerland

15. Department of Infectious and Tropical Diseases, Bégin Military Hospital, Saint-Mandé, France

16. Centro Hospitalar São João (Hospital Centre São João), International Health Unit, Porto, Portugal

17. European Centre for Disease Prevention and Control (ECDC), Stockholm, Sweden

18. ISTM/Geosentinel Statistician Consultant, Victoria, Canada

19. http://www.eurotravnet.eu

Citation style for this article:

Gautret P, Cramer JP, Field V, Caumes E, Jensenius M, Gkrania-Klotsas E, de Vries PJ, Grobusch MP, Lopez-Velez R, Castelli F, Schlagenhauf P, Hervius Askling H, von Sonnenburg F, Lalloo DG, Loutan L, Rapp C, Basto F, Santos O'Connor F, Weld L, Parola P, for the EuroTravNet Network. Infectious diseases among travellers and

migrants in Europe, EuroTravNet 2010. Euro Surveill. 2012;17(26):pii=20205. Available online: http://www.eurosurveillance.org/ViewArticle.aspx?Articleld=20205

To investigate trends in travel-associated morbidity with particular emphasis on emerging infections with the potential for introduction into Europe, diagnoses of 7,408 returning travellers presenting to 16 EuroTravNet sites in 2010 were compared with 2008 and 2009. A significant increase in reported Plasmodium falciparum malaria $(n=393$ ( $6 \%$ of all travel-related morbidity) vs. $\mathrm{n}=267$ (4\%) and 296 (5\%); p<0.001), P. vivax malaria $(n=53(1 \%)$ vs. $n=31(0.5 \%)$ and $39(1 \%)$; $p=0.038)$ and dengue fever $(n=327(5 \%)$ vs. $n=131(2 \%)$ and 172 (2\%); p<0.001) was observed. Giardia lamblia was identified in $16 \%$ of patients with acute diarrhoea, with no significant annual variation. The proportion of acute diarrhoea due to Campylobacter increased from $7 \%$ in 2008 to $12 \%$ in $2010(p=0.002)$. We recorded 121 patients with pulmonary tuberculosis in 2010, a threefold increase in the proportionate morbidity from 2008 to 2010. In 2010, 60 (0.8\%) cases of chronic Chagas disease, $151(2 \%)$ cases of schistosomiasis and 112 ( $2 \%$ ) cases of cutaneous larva migrans were reported. Illness patterns in sentinel travellers, captured by EuroTravnet, continue to highlight the potential role of travellers in the emergence of infectious diseases of public health concern in Europe and the relevance of offering medical travel advice and enforcing specific and adequate prophylaxis.*

\section{Introduction}

EuroTravNet (www.eurotravnet.eu), a network of clinicians who are specialists in tropical and travel medicine, was founded in 2008. It includes 16 EuroTravNet sites staffed by clinicians that have demonstrated training, experience, and/or significant publications in travel or tropical medicine. Sites in France, Germany, Italy, the Netherlands, Norway, Portugal, Spain, Sweden, Switzerland and the United Kingdom, participate in surveillance and monitoring of travel-related illnesses by collecting epidemiological data on returning ill travellers using the GeoSentinel technology platform (www.geosentinel.org) [1-3]. Network-based surveillance data allow for patient diagnoses, chronology of travel, and standardised exposure details to be collected for detailed analysis of travel-related morbidity. In addition, such networks can detect disease outbreaks through sentinel travellers, enhance surveillance, and facilitate rapid communication, response and dissemination of information among healthcare providers and public health partners. A good example of efficient detection of outbreaks among travellers was the recent report of a cluster of travellers returning from Tioman Island, Malaysia with muscular sarcocystosis [4]. 
This report describes the spectrum of selected infectious diseases in European travellers in 2010, and compares these numbers with the data sets from 2008 and 2009. Thanks to the multi-centre nature of EuroTravNet, which provided a large number of ill travellers from many countries with different reasons for travelling, we were able to capture statistically significant trends in imported infectious diseases over a relatively short period of three years.

\section{Methods}

The detailed methods for patient recruitment, inclusion criteria, and limitations of the GeoSentinel database have been described elsewhere [1-3,5]. In brief, patients must have crossed an international border, including borders within Europe, before the clinic visit and must have sought medical advice for a presumed travel-related illness or for screening for asymptomatic infection. All returned travellers presenting to EuroTravNet sites are systematically and prospectively included in the GeoSentinel database provided the diagnosis is clinically or laboratory-confirmed and that the causality of travel is confirmed. Travellers

\section{TABLE 1}

Number and percentage of travellers seen at the 16

EuroTravNet sites, 2008-2010 ( $\mathrm{n}=20,757)$

\begin{tabular}{|c|c|c|c|}
\hline Sites & 2008 & 2009 & 2010 \\
\hline Number (\%) & $6,957(100)$ & $6,392(100)$ & $7,408(100)$ \\
\hline \multicolumn{4}{|c|}{ France (3 sites) } \\
\hline Marseille & $351(5)$ & $496(8)$ & $395(5)$ \\
\hline Paris & $548(8)$ & $580(9)$ & $564(8)$ \\
\hline Saint Mandé & - & - & $201(3)$ \\
\hline \multicolumn{4}{|c|}{ Germany (2 sites) } \\
\hline Hamburg & $1,480(21)$ & 806 (13) & $1,050(14)$ \\
\hline Munich & $1,547(22)$ & $1,441(23)$ & $1,365(18)$ \\
\hline \multicolumn{4}{|l|}{ Italy (1 site) } \\
\hline Brescia & $136(2)$ & $246(4)$ & $237(3)$ \\
\hline \multicolumn{4}{|c|}{ Norway (1 site) } \\
\hline Oslo & $498(7)$ & $476(7)$ & $588(8)$ \\
\hline \multicolumn{4}{|c|}{ Portugal (1 site) } \\
\hline Porto & - & - & $8(41)$ \\
\hline \multicolumn{4}{|c|}{ Sweden (1 site) } \\
\hline Stockholm & - & - & $416(6)$ \\
\hline \multicolumn{4}{|c|}{ Switzerland (2 sites) } \\
\hline Geneva & $417(6)$ & $293(5)$ & $385(5)$ \\
\hline Zurich & $225(3)$ & $132(2)$ & $245(3)$ \\
\hline \multicolumn{4}{|l|}{ Spain (1 site) } \\
\hline Madrid & $456(7)$ & $217(3)$ & $225(3)$ \\
\hline \multicolumn{4}{|c|}{ The Netherland (1 site) } \\
\hline Amsterdam & $41(1)$ & $670(11)$ & $507(7)$ \\
\hline \multicolumn{4}{|c|}{ United Kingdom (3 sites) } \\
\hline Cambridge & $126(2)$ & $125(2)$ & $152(2)$ \\
\hline Liverpool & - & - & $52(1)$ \\
\hline London & $1,132(16)$ & $910(14)$ & $1,018(14)$ \\
\hline
\end{tabular}

undergoing screening for asymptomatic infections or clinically cured travellers looking for a confirmation of the diagnosis established elsewhere are however also included in the database, with "healthy" as a diagnosis when the screening remains negative. Patients included in the study may be symptomatic or not. For example, patients with chronic infection such as Chagas disease, schistosomiasis, tuberculosis, hepatitis $B$, were included whether or not they had clinical symptoms at the time they presented*. Anonymous, almost real-time, surveillance data that cannot be linked to individual patients are entered into the GeoSentinel database. Final diagnoses are assigned by the treating clinician from an internal standardised GeoSentinel list of more than 500 possible individually coded diagnoses [5]. Patients can be assigned as many diagnostic codes as applicable. All sites use the best available reference diagnostic tests and clinical protocols in their respective countries. Travellers who presented between 1 January 2010 and 31 December 2010 to a EuroTravNet site during or after travel were included in this analysis and were compared with travellers who presented in EuroTravNet sites between 1 January and 31 December in 2008 and 2009. Sites see two distinct groups of patients. The first group represents travellers on short trips, including mainly tourists, business travellers and non-recent migrants or their descendants visiting friends and relatives in their origin countries (VFRs), but also missionaries, volunteer workers, aid workers and researchers, students travelling for field work, military personnel on missions, and individuals travelling to seek medical care (medical tourism). The second group represents travellers with long-time exposure abroad including mainly recent immigrants, usually seen for screening when they first enter the migration country, and long-term exposed expatriates (missionaries, volunteers, aid workers and researchers as well as people staying abroad for business).

Data were analysed using SPSS, v16.0 (SPSS Inc, Chicago). We calculated proportionate morbidities by comparing the number of cases of a specific diagnosis (or of a group of specific diagnoses within a syndrome group) with all cases of returning ill travellers seen during the same time period (or to sub-groups of travellers). This allowed us to make comparisons over time and between subgroups. Differences in proportions between sub-groups of returning ill travellers seen at EuroTravNet sites were tested using Pearson's Chi-square or Fisher's exact tests. A p value of under 0.01 was chosen as significant to take into account the large number of statistical tests performed. One new site had joined EuroTravNet in late 2008, and four new sites had joined EuroTravNet in 2010, contributing together $10 \%$ of cases in 2009 and $16 \%$ in 2010. To allow a reliable comparison by year, cases reported by sites that joined after mid-2008 were excluded for trend analysis. 


\section{Results}

In 2010, data from 7,408 ill travellers were collected. There were no significant changes from 2008 to 2010 in the number of patients seen at each site (Table 1), nor in the age and sex distribution of patients. More nonVFR short-term travellers were hospitalised in 2009 and 2010 than in 2008, and fewer patients were known to have received a pre-travel consultation (Tables 2 and 3). The results remained the same when the new sites were excluded.
Mortality observed in imported diseases

Five deaths were recorded in 2010. A French tourist in their 30 died in Switzerland of melioidosis with septic shock, multi-organ failure and acute respiratory distress syndrome after a trip to Martinique [6]. A migrant from India in their 30 s died in Brescia with a diagnosis of pyogenic liver abscesses and diabetes mellitus. A Swiss in their 50 s tourist died of disseminated Salmonella enterica serovar Weltevreden infection after returning to Switzerland from Puerto Rico. A Norwegian tourist in their 6os died of Legionnaires' disease after a returning from the Czech Republic. A Portuguese

\section{TABLE 2}

Demographic characteristics of immigrants and expatriates (long-term exposure) seen at the 16 EuroTravNet sites, 2008$2010(\mathrm{n}=3,494)$

\begin{tabular}{|c|c|c|c|c|c|c|}
\hline \multirow[b]{2}{*}{ Year } & \multicolumn{3}{|c|}{ Immigrants } & \multicolumn{3}{|c|}{ Expatriates } \\
\hline & 2008 & 2009 & 2010 & 2008 & 2009 & 2010 \\
\hline Number & 656 & 489 & 639 & 479 & 548 & 683 \\
\hline Sex (\%) Female & $311(47)$ & $215(44)$ & $298(47)$ & $230(48)$ & $292(53)$ & $341(50)$ \\
\hline \multicolumn{7}{|l|}{ Age (years) } \\
\hline Mean & 32.6 & 31.6 & 32.9 & 40.2 & 37 & 36.8 \\
\hline 25th percentile & 26 & 24 & 25 & 30 & 29 & 28 \\
\hline Median & 32 & 30 & 32 & 40 & 38 & 38 \\
\hline 75th percentile & 39 & 38 & 39 & 53 & 48 & 50 \\
\hline \multicolumn{7}{|l|}{ Travel reason (\%) } \\
\hline Business & - & - & - & $123(26)$ & 105 (19) & $150(22)$ \\
\hline Immigration & $656(100)$ & $489(100)$ & $639(100)$ & - & - & - \\
\hline Medical tourism & - & - & - & $\mathrm{o}(\mathrm{o})$ & $\mathrm{o}(\mathrm{o})$ & $\mathrm{o}(\mathrm{o})$ \\
\hline Military & - & - & - & $\mathrm{o}(0)$ & o (o) & o (o) \\
\hline$M / \mathrm{V} / \mathrm{AW} / \mathrm{R}$ & - & - & - & $348(73)$ & $442(81)$ & $533(78)$ \\
\hline Student & - & - & - & o (o) & $1(0)$ & o (o) \\
\hline Tourism & - & - & - & $6(1)$ & $\mathrm{o}(\mathrm{o})$ & $\mathrm{o}(\mathrm{o})$ \\
\hline \multicolumn{7}{|l|}{ Risk level (\%) } \\
\hline Expatriate & - & - & - & $479(100)$ & $548(100)$ & $683(100)$ \\
\hline Pre-arranged or organised travel & - & - & - & - & - & - \\
\hline Risk travel ${ }^{\mathrm{a}}$ & $656(100)$ & $489(100)$ & $639(100)$ & - & - & - \\
\hline \multicolumn{7}{|l|}{ Clinical setting (\%) } \\
\hline Immigration only & $656(100)$ & $489(100)$ & $639(100)$ & - & - & - \\
\hline Seen after travel & - & - & - & $272(57)$ & $320(58)$ & $367(54)$ \\
\hline Seen during travel & - & - & - & $207(43)$ & $228(42)$ & $316(46)$ \\
\hline Inpatient (\%) & $106(16)$ & $166(34)$ & $243(38)$ & $23(5)$ & $15(3)$ & $29(4)$ \\
\hline \multicolumn{7}{|l|}{ Pre-travel consultation (\%) } \\
\hline Yes & $9(1)$ & $6(1)$ & $4(1)$ & $301(63)$ & $365(66)$ & $434(64)$ \\
\hline No & $60(9)$ & $130(27)$ & $144(23)$ & $54(11)$ & $41(8)$ & $76(11)$ \\
\hline Do not know & $587(90)$ & $353(72)$ & $491(77)$ & $124(26)$ & $143(26)$ & $173(25)$ \\
\hline \multicolumn{7}{|l|}{ Live in Europe (\%) } \\
\hline Yes & $654(100)$ & $489(100)$ & $639(100)$ & $244(51)$ & $318(58)$ & $396(58)$ \\
\hline \multicolumn{7}{|l|}{ Born in Europe (\%) } \\
\hline Yes & $28(4)$ & $26(5)$ & $62(10)$ & $423(88)$ & $474(87)$ & $568(83)$ \\
\hline
\end{tabular}

AW: aid worker; M: missionary; R: researcher; V: volunteer; VFR: visiting friends and relatives.

a Risk travel: intended to identify travellers who will, by their behaviour, encounter a substantial number of the risks faced by the local population. This classification would generally include travelling without pre-booking accommodation for most or all nights, using accommodation specific to budget travellers and/or staying in local residents' homes. 
business traveller in their 50 s died with a Plasmodium falciparum infection and acute respiratory distress syndrome after a four-month stay in Angola. This patient had not taken anti-malarial prophylaxis. The overall mortality rate was 0.7 per 1,000 ill travellers in 2010, compared with 0.3 per 1,000 in 2009 (two deaths due to visceral leishmaniasis, and Acinetobacter sp. pneumonia) and with 0.4 per 1,000 in 2008 (three deaths due to $P$. falciparum cerebral malaria, dengue shock syndrome and $E$. coli pyelonephritis) $[2,3]$. The mortality rate associated with malaria was 1.7 per 1,000 malaria cases in 2010, compared with o per 1,000 in 2009 and 2.7 per 1,000 in 2008.

\section{Spectrum of imported diseases}

Among diagnoses with an identified pathogen (Tables 4 and 5), malaria and dengue fever accounted for most cases of febrile systemic illnesses. Giardia lamblia was the most common pathogen identified in acute diarrhoea, followed by Campylobacter and Salmonella spp. Other common parasitic infections included

\section{TABLE 3}

Demographic characteristics of patients visiting friends and relatives and other short-term travellers seen at the 16 EuroTravNet sites, 2008-2010 ( $\mathrm{n}=17,263)$

\begin{tabular}{|c|c|c|c|c|c|c|}
\hline \multirow[b]{2}{*}{ Year } & \multicolumn{3}{|c|}{ VFRs } & \multicolumn{3}{|c|}{ Other short-term travellers } \\
\hline & 2008 & 2009 & 2010 & 2008 & 2009 & 2010 \\
\hline Number & 831 & 800 & 942 & 4,991 & 4,555 & 5,144 \\
\hline Sex (\%) Female & $347(42)$ & $350(44)$ & $403(43)$ & $2,510(50)$ & $2,355(52)$ & $2,561(50)$ \\
\hline \multicolumn{7}{|l|}{ Age (years) } \\
\hline Mean & 33.3 & $34 \cdot 7$ & 36.7 & 38.5 & 37.9 & 38.7 \\
\hline Median & 34 & 35 & 37 & 36 & 35 & 36 \\
\hline 75th percentile & 45 & 45 & 46 & 49 & 48 & 49 \\
\hline \multicolumn{7}{|l|}{ Travel reason (\%) } \\
\hline Business & - & - & - & $606(12)$ & $600(13)$ & $741(14)$ \\
\hline Immigration & - & - & - & - & - & - \\
\hline Medical tourism & - & - & - & $10(0)$ & $24(1)$ & $27(1)$ \\
\hline $\mathrm{M} / \mathrm{V} / \mathrm{AW} / \mathrm{R}$ & - & - & - & $1,221(25)$ & $838(18)$ & $996(19)$ \\
\hline Student & - & - & - & $91(2)$ & $157(3)$ & $131(3)$ \\
\hline Tourism & - & - & - & $3,023(61)$ & $2,875(63)$ & $3,176(62)$ \\
\hline VFRs & $831(100)$ & $800(100)$ & $942(100)$ & - & - & - \\
\hline \multicolumn{7}{|l|}{ Risk level (\%) } \\
\hline Expatriate & - & - & - & - & - & - \\
\hline Pre-arranged or organised travel & - & - & - & $1,570(32)$ & $1,698(37)$ & $2,015(39)$ \\
\hline Risk travel $^{\mathrm{a}}$ & $831(100)$ & $800(100)$ & $942(100)$ & $3,367(68)$ & $2,780(61)$ & $3,074(60)$ \\
\hline Missing information & - & - & - & $54(1)$ & $77(2)$ & $55(1)$ \\
\hline \multicolumn{7}{|l|}{ Clinical setting (\%) } \\
\hline Immigration only & - & - & - & - & - & - \\
\hline Seen after travel & 819 (99) & 779 (97) & 934 (99) & $4,616(93)$ & $4,296(94)$ & $4,895(95)$ \\
\hline Inpatient (\%) & $261(31)$ & $290(36)$ & $390(41)$ & $379(8)$ & $461(10)$ & $682(13)$ \\
\hline \multicolumn{7}{|l|}{ Pre-travel consultation (\%) } \\
\hline Yes & $203(24)$ & $212(27)$ & $221(24)$ & $2,647(53)$ & $2,182(48)$ & $2,321(45)$ \\
\hline No & $329(40)$ & $381(48)$ & $472(50)$ & $1,111(22)$ & $1,116(25)$ & $1,524(30)$ \\
\hline Do not know & $299(36)$ & $207(26)$ & $249(26)$ & $1,233(25)$ & $1,257(28)$ & $1,299(25)$ \\
\hline \multicolumn{7}{|l|}{ Live in Europe (\%) } \\
\hline Yes & $817(98)$ & $782(98)$ & 934 (99) & $4,640(93)$ & $4,324(95)$ & 4,933 (96) \\
\hline \multicolumn{7}{|l|}{ Born in Europe (\%) } \\
\hline Yes & $260(31)$ & $239(30)$ & $264(28)$ & $4,570(92)$ & $4,214(93)$ & 4,757 (93) \\
\hline
\end{tabular}

AW: aid worker; M: missionary; R: researcher; V: volunteer; VFR: visiting friends and relatives.

a Risk travel: intended to identify travellers who will, by their behaviour, encounter a substantial number of the risks faced by the local population. This classification would generally include travelling without pre-booking accommodation for most or all nights, using accommodation specific to budget travellers and/or staying in local residents' homes. 


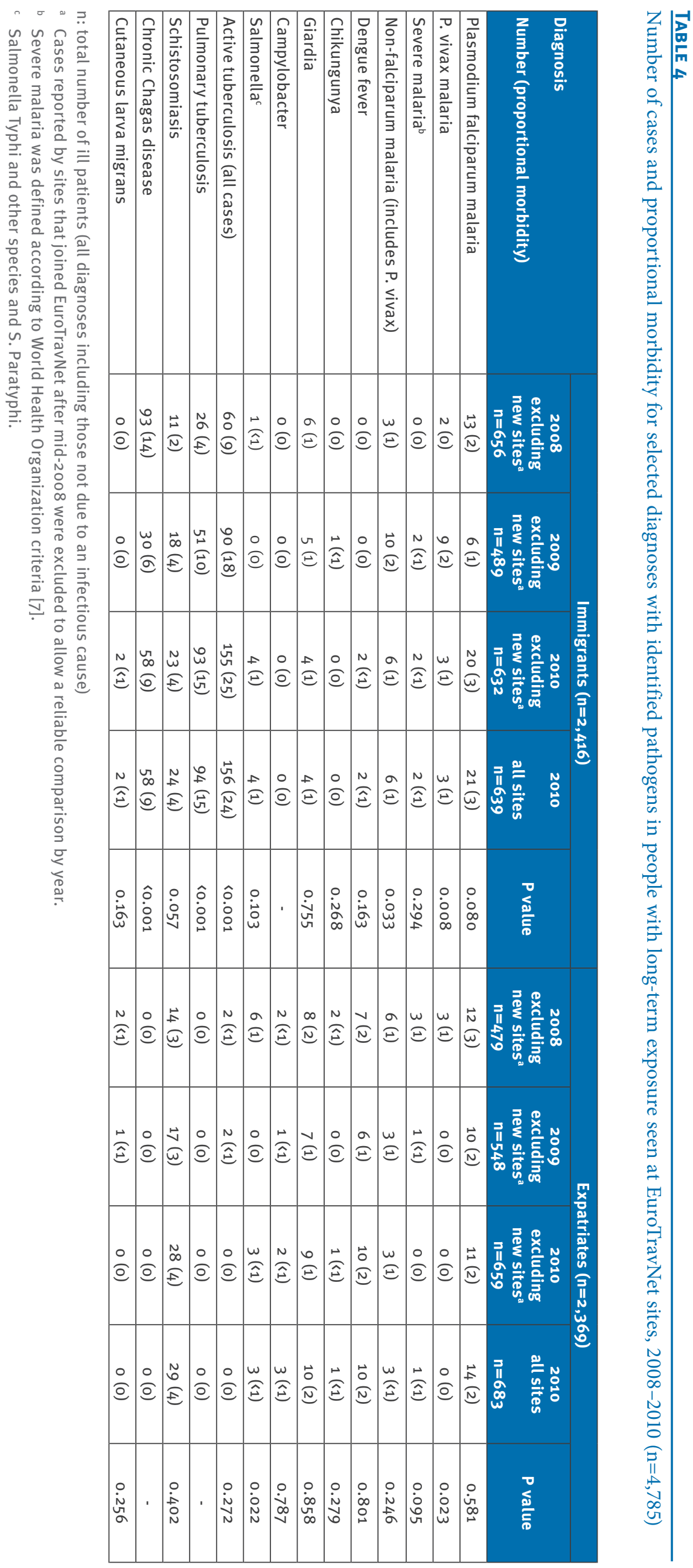




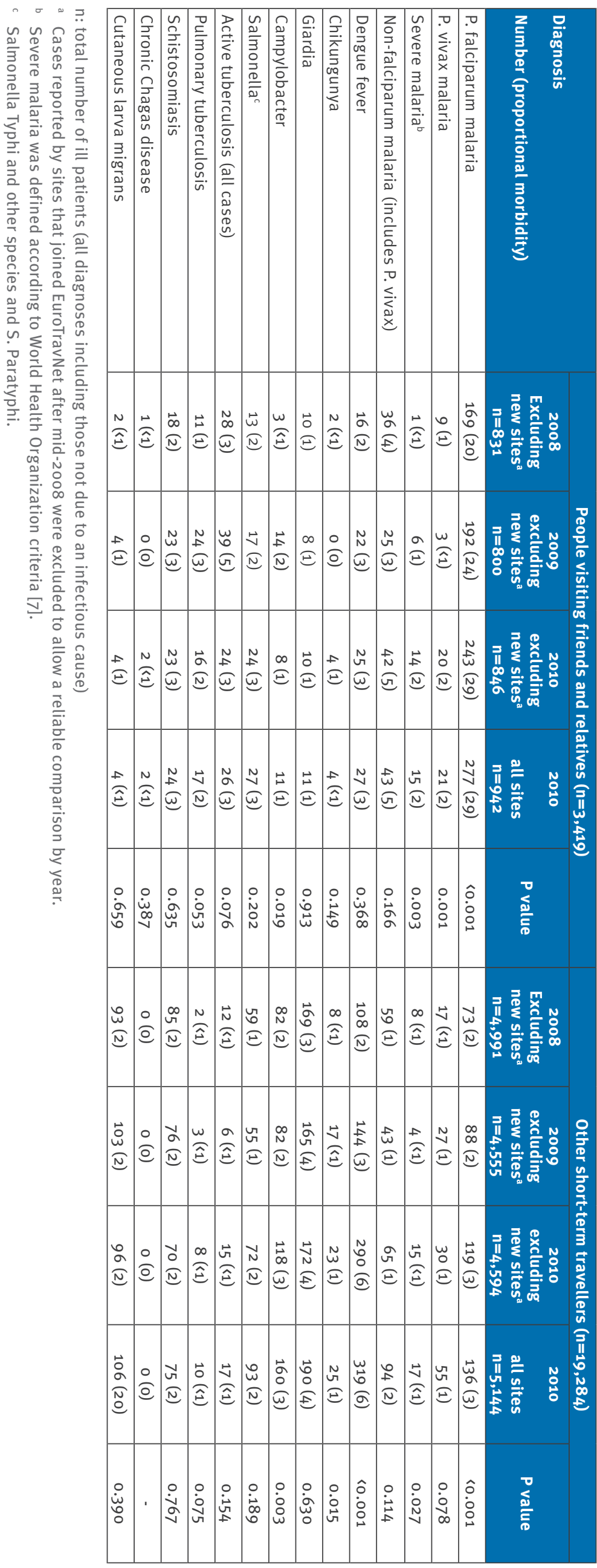

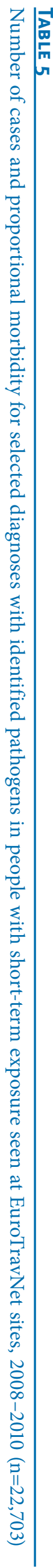


hookworm-related cutaneous larva migrans (CLM), schistosomiasis and chronic Chagas disease.

\section{Febrile systemic illnesses}

\section{Malaria}

There was an increase in malaria cases reported from 2008 to 2010 at the EuroTravNet sites, even after the exclusion of sites that joined EuroTravNet after mid2008 (Figure 1). The proportionate morbidity from malaria was dramatically higher in VFRs than in other groups. A significant increase over time in numbers and proportionate morbidity was observed in both the group of VFRs and other traveller groups (Figure 2). The increase was observed in patients returning from all main countries of exposure for malaria with the exception of Burkina Faso where no variation was seen overtime (Figure 1). There was a significant increase in the proportion of patients with malaria seen at the sites in Paris (France) and Brescia (Italy), which together contributed more than half of the cases ( $57 \%$ in 2010), as well as in those seen in Munich and Hamburg (Germany) and Madrid (Spain) (Figure 2).

Plasmodium falciparum malaria was the most commonly reported species with 426 cases in 2010. $P$. falciparum malaria proportionate morbidity (number of $P$. falciparum malaria cases per 100 ill travellers) increased from $4 \%$ in 2008 to $6 \%$ in 2010 (p<0.001), primarily in patients returning from sub-Saharan Africa. Most cases were in VFRs and other short-term travellers. There were 31 patients with severe $P$. falciparum malaria (one death) in 2010 compared with 13 in 2009 (no deaths) and 12 in 2008 (one death) ( $p=0.002)$. In 2010, the mean age of patients with severe malaria was 39.6 years (range 3-73 years), four patients were children. Eight of those patients were tourists, seven were business travellers, volunteers, research or aid workers, while the remaining 16 were immigrants or VFRs (54\%).*

Plasmodium vivax malaria proportionate morbidity (number of $P$. vivax malaria cases per 100 ill travellers) increased from $0.5 \%$ in 2008 to $1 \%$ in 2010 ( $p=0.038)$. Most cases were VFRs and other short-term travellers returning from India.*

\section{Dengue virus infection}

Dengue virus was the second most frequent cause of fever among ill returning travellers, with 357 patients in 2010. There was a statistically significant increase in proportional morbidity, from $2 \%$ in 2008 to $5 \%$ in 2010 ( $p<0.001$ ). Most cases were in non-VFR short-term travellers. The 2009-10 increase was primarily due to a peak of cases between May and October 2010 (Figure 3). In 2010, patients returning from south-east Asia accounted for $40 \%$ of dengue patients, those from the Caribbean for $24 \%$ and those from South America for $12 \%$. The seasonal pattern could be partly explained by preferential destinations of different traveller
FIGURE 1

Number of all malaria cases per year reported by EuroTravNet sites, 2008-2010 $(\mathrm{n}=1,245)$

A. By countries of exposure (top 12) $(n=954)$

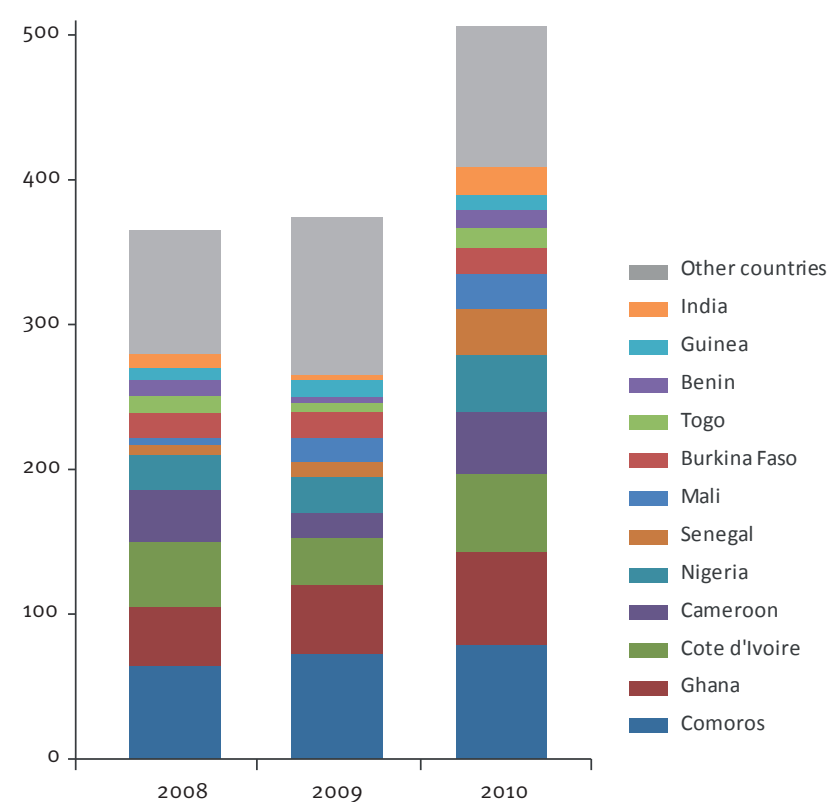

B. By reporting site $(n=1,245)$

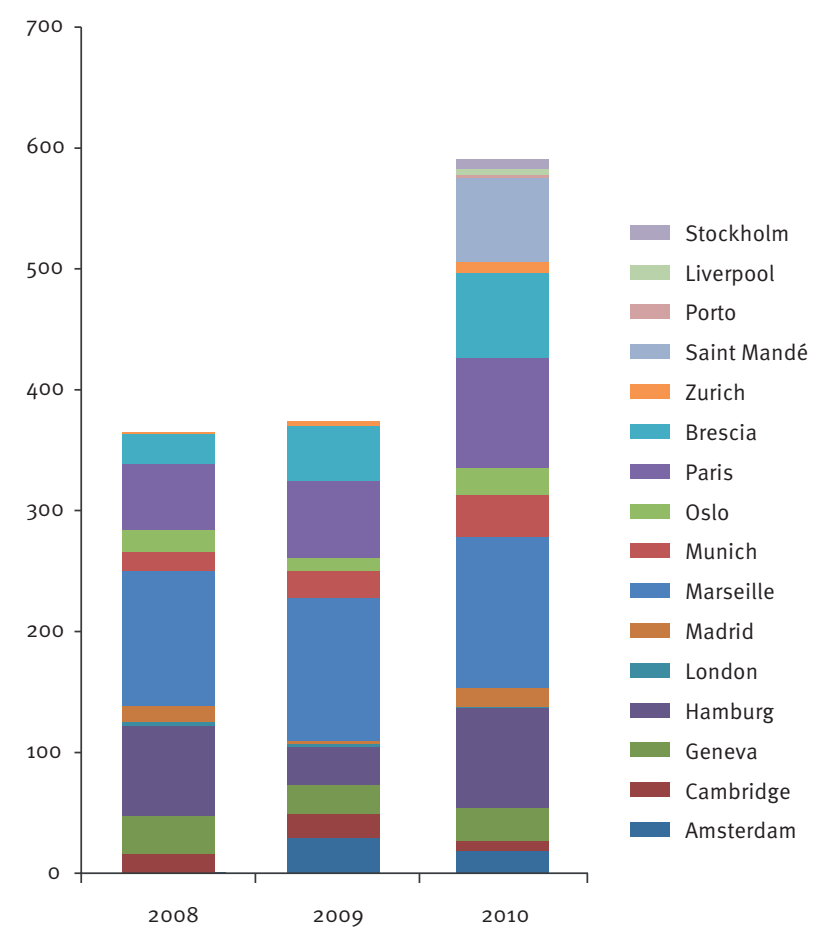

Cases reported by sites that joined EuroTravNet after mid-2008 were excluded to allow a reliable comparison by year. 


\section{FIGURE 2}

Proportion of malaria cases among all ill immigrants, people visiting friends and relatives, and other travellers returning to EuroTravNet sites, 2008-2010 (n=1,245 malaria cases)

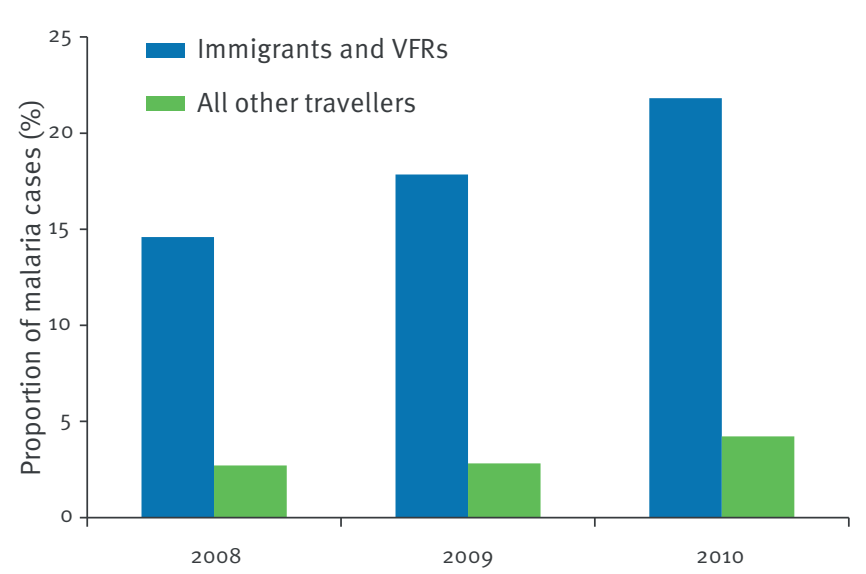

VFR: visiting friends and relatives.

groups. Consequently, in September 2010, there were more patients, predominantly Germans, with exposure in south-east Asia, mainly Thailand. From June to September 2010, there were more French patients with exposure in Guadeloupe and Martinique. The increase in October 2010 was spread over different EuroTravNet sites and exposure countries, but German patients returning from Indonesia were overrepresented. Cases were also seen in 2010 in travellers returning from Brazil, Surinam and India. Unexpected places of exposure, such as the Comoros Islands, Zanzibar and Benin were also recorded. There was one case of haemorrhagic dengue fever in a 53 year-old French male VFR from Martinique.

\section{Chilkungunya virus infections}

The proportionate morbidity for diagnosed chikungunya virus infections was $0.2 \%$ in 2008 and $0.4 \%$ on 2010. Most patients had exposure in India and Indonesia and occurred in early 2010.

\section{Gastro-intestinal diseases}

A total of $215 \mathrm{G}$. lamblia infections were recorded in 2010. While G. lamblia and Salmonella spp. proportionate morbidity remained constant over time, the proportionate morbidity of Campylobacter spp. infections increased from $1.3 \%$ in 2008 to $1.9 \%$ in $2010(p=0.008)$, mainly in patients returning from India, Thailand and Pakistan. G. lamblia was identified in $16 \%$ of patients with acute diarrhoea. The proportion of patients with acute diarrhoea due to Campylobacter increased from $7 \%$ in 2008 to $12 \%$ in $2010(\mathrm{p}=0.002)$.*

\section{FIGURE 3}

Number of dengue fever cases seen at EuroTravNet sites, per month, 2008-2010 $(\mathrm{n}=630)$

A. All cases $(n=630)$

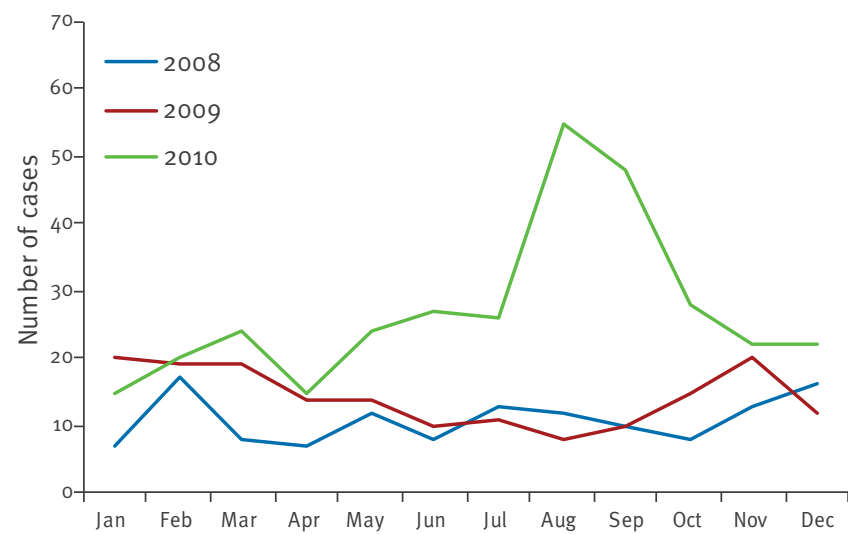

B. Travellers returning from south-east Asia $(n=255)$

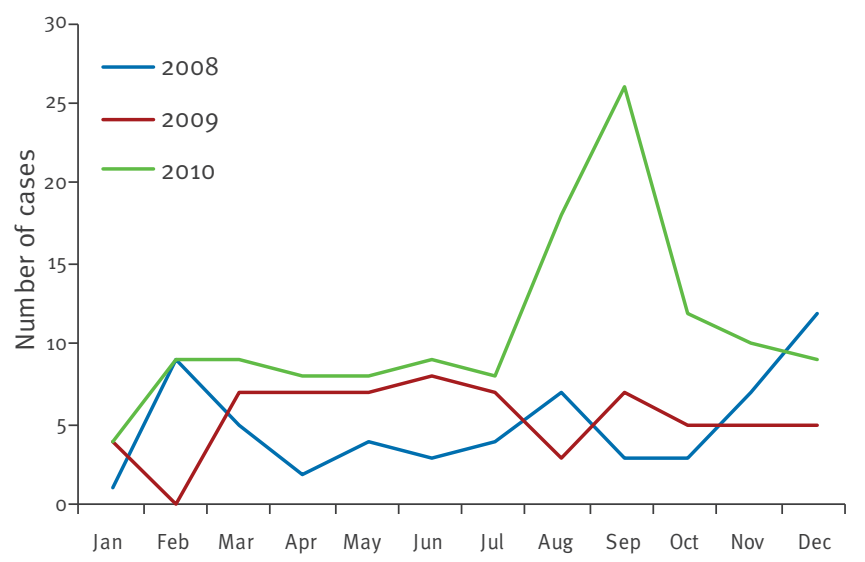

C. Travellers returning from the Caribbean $(n=108)$

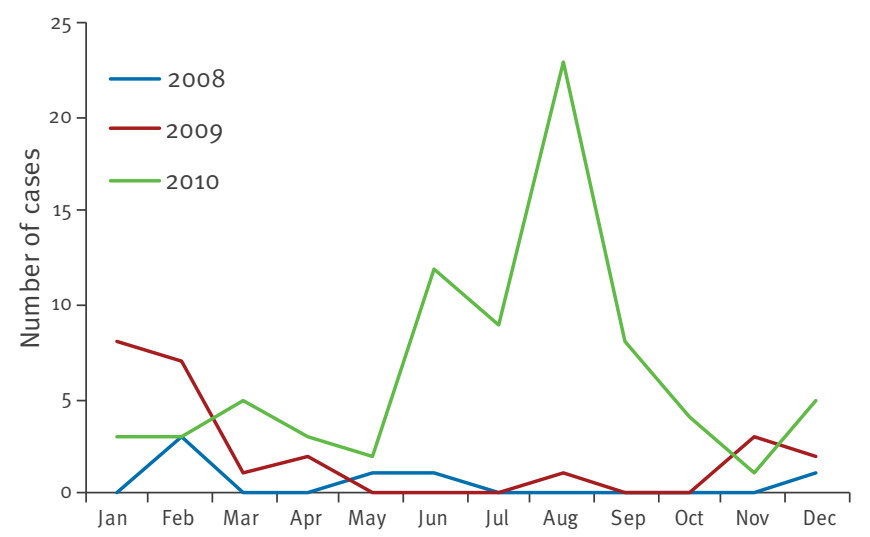

Cases reported by sites that joined EuroTravNet after mid-2008 were excluded to allow a reliable comparison by year. 


\section{Respiratory and other diseases}

\section{Tuberculosis}

The proportionate morbidity of active tuberculosis increased from $1.5 \%$ in 2008 to $2.9 \%$ in 2010 (p<0.001). A total of 121 patients with pulmonary tuberculosis were recorded in 2010, a threefold increase in the proportionate morbidity of pulmonary tuberculosis from 2008 to 2010 (p<0.001). Most cases were reported in immigrants and VFRs, originating mainly from India, Pakistan and Romania. *

\section{Other parasitic infections}

In 2010, 152 Schistosoma infections were recorded and most cases were diagnosed in patients returning from Africa. Egypt, Ghana, Malawi, Mali and Uganda accounted for $41 \%$ of infections. Six patients may have acquired schistosomiasis in south-east Asia and two in Brazil. Most Schistosoma infections (40\%) occurred in missionaries, volunteers and aid workers, followed by tourists (19\%), VFRs (16\%) and immigrants (13\%). In 2010, 112 CLM infections were recorded and most cases were acquired in Thailand, Brazil and Malaysia (46\%) and mostly reported from tourists $(80 \%)$ followed by business travellers (6\%). In 2010, 60 cases of Chagas disease were recorded. All but two patients diagnosed with Chagas disease were immigrants from Bolivia; the other two were from Paraguay and Ecuador. Two thirds of the patients $(67 \%)$ had symptoms that could be attributed to Chagas disease, and $21 \%$ of those had confirmed visceral involvement and $79 \%$ were in the indeterminate phase. The proportionate morbidities of schistosomiasis, CLM and Chagas disease did not increase significantly from 2008 to 2010 .

\section{Discussion}

Between 2008 and 2010, 10 deaths were reported among travellers seen within our network. This may significantly underestimate the travel-related mortality in Europe, as it does not include patients who died overseas or patients not seen in our centres. In other series published in the last decade on patients with imported infections presenting with fever, malaria was found to be the most important cause of travel-related mortality [8]. Case fatality rates of imported malaria do not fluctuate much and have been about 0.5 to $1 \%$ of reported cases in the past 20 years $[9,10]$ compared with less than $0.4 \%$ in our experience.

We observed distinct patterns of morbidity related to the duration of stay in tropical areas. Malaria, dengue and chikungunya virus infections, diarrhoea and CLM were mostly seen in short-term travellers, while tuberculosis, Chagas disease and Schistosoma infections were mostly seen in long-term travellers. Reason for travel was also associated with some infections, including malaria in VFRs, CLM in tourists, or tuberculosis and Chagas disease in immigrants.

Malaria remains the most common cause of fever among travellers to tropical countries receiving a diagnosis in the EuroTravNet/Geosentinel database. The significant increase in malaria cases reported to EuroTravNet in 2010 confirms the trend already observed in 2009 [3] and was not biased by the addition of new sites to the network in 2010 nor by an overall increase of patients seen at each EuroTravNet clinic. It may reflect a changing trend in imported malaria in Europe, possibly due to changes in destinations. However, the increase was statistically significant in only five EuroTravNet sites. Despite a global trend in declining malaria case numbers in endemic areas over the past decade, World Health Organization (WHO) statistics on imported malaria cases in Europe show a contradictory trend with increased case numbers in the past two years [11] which calls for intensified EuroTravNet surveillance of malaria in travellers and migrants. According to data from the WHO, the overall incidence of imported malaria in the European Union had decreased gradually from 2.9 cases per 100,000 population in 2000 to 1.64 per 100,000 in 2008 , but there was a slight increase to 1.67 per 100,000 in $2009[11,12]$. This correlates with our own results, with national malaria surveillance data in France that estimated 3,990 imported cases in 2009 and 4,600 in 2010 [13], and also with data from the United Kingdom, where 1,370 imported cases were recorded in 2008, 1,495 in 2009 and 1,761 in 2010 [14]. Odolini et al, [3] emphasised the public health consequences of increasing importation of $P$. vivax malaria to Mediterranean Europe that could lead to the reappearance of autochthonous malaria. Sporadic cases of autochthonous $P$. vivax malaria have already been observed in southern France [15] and Spain [16] and more recently in Greece $[17,18]$. Given the high proportion of immigrants and VFRs among malaria patients, specific health education programmes should be launched in these populations who are known to seek pre-travel advice less frequently compared with other travellers [17], which is confirmed in our survey (see Tables 2 and 3). This is important because patients with P.vivax malaria could act as reservoirs for autochthonous transmission in Europe.

We highlight that dengue virus is an increasingly frequent cause of fever in travellers returning from the tropics, which corroborates results from single-centre surveys recently conducted in Germany, Denmark and the Netherlands [18-22]. The increased incidence of dengue fever in travellers returning from southeast Asia and from the Caribbean may be the consequence of outbreaks that occurred in these areas in 2010 [24,24]. Surveillance of sentinel travellers allows us to identify dengue virus circulation in areas where it was unknown or rarely described, notably in Benin and the Comoros Islands $[25,26]$. Whether this reflects extremely rare transmission from sylvatic animals to humans or transmission between humans, is not clear. A number of patients with dengue and chikungunya virus infections in our survey were recorded in southern France and Italy where autochthonous transmission has recently been observed [27-29]. Overall, $16 \%$ of patients with chikungunya fever were seen 
in Marseille, where Aedes albopictus has recently been detected [30]. This emphasises the need for increased attention to surveillance of dengue and chikungunya fever in travellers returning to areas where A. albopictus is present.

The high proportion of $\mathrm{G}$. lamblia infections among European travellers suffering from diarrhoea is noteworthy. Travellers should receive stool examinations especially in the context of chronic gastrointestinal complaints accompanied by intermittent diarrhoea. Data on imported resistant bacteria are not systematically reported to the EuroTravNet database. However, most cases of diarrhoea due to Campylobacter and Salmonella spp. followed exposure in Asian countries where fluoroquinolone resistance is common [31,32]. This suggests that fluoroquinolones should no longer be prescribed as first-line empiric treatment for travellers' diarrhoea. A macrolide such as azithromycin may be a better choice [31].

Our survey confirms that tuberculosis is an issue in immigrants coming to Europe from high-incidence countries. In the author's view, health systems should facilitate early access and treatment of patients with tuberculosis (regardless of their legal status) to prevent further spread of the disease. In addition, substantial numbers of chronic Chagas disease were reported to EuroTravNet in 2010, mainly at the site in Madrid among immigrants from Bolivia. This is comparable to the data from 2008-09 [33].

Schistosomiasis and CLM continue to cause a significant proportion of imported parasitic diseases in European travellers. Schistosomiasis is easily prevented by avoiding swimming in open water, and this recommendation should be re-enforced when giving pre-travel advice. CLM is more difficult to prevent because most tourist travellers acquire this disease during typical holiday leisure activities on the beaches and prevention is mainly by public health measures that keep dogs and cats off the beach.

The major strength of our analysis is the multi-centre nature of EuroTravNet, which provided a large number of patients from many countries and captured many types of travellers, and its focus on proportionate morbidity. The limitations of this method of analysis have been discussed $[1,5]$. In particular, because the denominator data (number of travellers) cannot be ascertained, it is not possible to calculate incidence rates or absolute risk. Also, the data may not be representative of the overall population of travellers, and do not include the broad spectrum of illnesses typically seen at nonspecialised primary care practices where people with mild or self-limited conditions present with higher frequency. Due to the nature of GeoSentinel/EuroTravNet clinics, illnesses acquired after travel to non-tropical destinations or non-infectious travel-related illnesses may be under-represented. However, the GeoSentinel database has been identified as a valuable source of data on the epidemiology of travel-related illnesses [34]. Surveillance over this three-year period also identified an increase in imported vector-borne diseases at European sentinel sites with significantly raised numbers of malaria and dengue fever. This has important public health implications and warrants close surveillance in view of the presence in Europe of Anopheles (competent for $P$. vivax transmission) and Aedes vectors (competent for dengue and chikungunya virus transmission), allowing real-time intervention to prevent subsequent autochthonous transmission.

Finally, it is of concern that there were more hospitalised patients and fewer patients who were known to have had a pre-travel consultation, compared with 2008-09. This should alert public health authorities to the need to reinforce preventive activities among international travellers.

In summary, we have investigated travel-associated morbidity in European travellers in 2010 and showed that illness patterns in sentinel travellers, captured through the activities of the EuroTravnet/Geosentinel Network, continue to highlight the potential role of travellers in the emergence of infectious diseases of public health concern in Europe.

\section{* Authors' correction:}

The sentences "All ill patients presenting to EuroTravNet sites are systematically and prospectively included in the GeoSentinel database provided the diagnosis is clinically or laboratory-confirmed and that the causality of travel is confirmed. All patients included in the study were symptomatic, including those with parasitic infections such as malaria and schistosomiasis. Patients with proven chronic Chagas infection, however, were included whether or not they were symptomatic, owing to the potential life-threatening course of the disease." were corrected to read: "All returned travellers presenting to EuroTravNet sites are systematically and prospectively included in the GeoSentinel database provided the diagnosis is clinically or laboratory-confirmed and that the causality of travel is confirmed. Travellers undergoing screening for asymptomatic infections or clinically cured travellers looking for a confirmation of the diagnosis established elsewhere are however also included in the database, with "healthy" as a diagnosis when the screening remains negative. Patients included in the study may be symptomatic or not. For example, patients with chronic infection such as Chagas disease, schistosomiasis, tuberculosis, hepatitis B, were included whether or not they had clinical symptoms at the time they presented." . This correction was made on 12 November 2012 at the request of the authors.

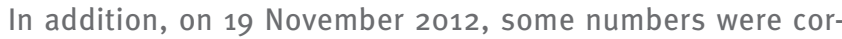
rected at the request of the authors in the abstract and in the main text (making no interpretation difference). 


\section{Acknowledgements}

We are grateful to D. Freedman for helpful comments. In addition to the authors, members of the EuroTravNet/GeoSentinel Networks, who contributed data are M. van Vugt, P.P.A.M. van Thiel, A. Goorhuis, C. Stijnis, B. Goorhuis, F. Simon, H. Savini.

EuroTravNet (http://www.eurotravnet.eu) is the European Centre for Disease Prevention and Control corresponding network for tropical and travel medicine, funded through the public tenders 0J/2008/07/08-PROC/2008/019 and 0J/2010/ $03 / 16-P R O C / 2010 / 011$. It has been created by grouping the European sites of GeoSentinel (http://www.geosentinel.org), the Global Surveillance Network of the International Society of Travel Medicine, supported by Cooperative Agreement U50 Cloo0359 from the US CDC.

\section{References}

1. Gautret $P$, Schlagenhauf $P$, Gaudart J, Castelli F, Brouqui $P$ von Sonnenburg F, et al. Multicenter EuroTravNet/GeoSentinel study of travel-related infectious diseases in Europe. Emerg Infect Dis. 2009;15(11):1783-90.

2. Field V, Gautret P, Schlagenhauf P, Burchard GD, Caumes $E$, Jensenius $M$, et al. Travel and migration associated infectious diseases morbidity in Europe, 2008. BMC Infect Dis. 2010;10:330.

3. Odolini S, Parola P, Gkrania-Klotsas E, Caumes E, Schlagenhauf P, López-Vélez R, et al. Travel-related imported infections in Europe, EuroTravNet 2009. Clin Microbiol Infect. 2012;18(5):468-74.

4. Centers for Disease Control and Prevention (CDC). Notes from the field: acute muscular sarcocystosis among returning travelers - Tioman Island, Malaysia, 2011. MMWR Morb Mortal Wkly Rep. 2012;61(2):37-8.

5. Freedman DO, Weld LH, Kozarsky PE, Fisk T, Robins R, von Sonnenburg F, et al. Spectrum of disease and relation to place of exposure among ill returned travelers. N Engl J Med. 2006;354(2):119-30.

6. Gétaz L, Abbas M, Loutan L, Schrenzel J, Iten A, Simon F, et al. Fatal acute melioidosis in a tourist returning from Martinique Island, November 2010. Euro Surveill. 2011;16(1).pii=19758. Available from: http://www.eurosurveillance.org/ViewArticle. aspx?Articleld $=19758$

7. Severe falciparum malaria. World Health Organization, Communicable Diseases Cluster. Trans R Soc Trop Med Hyg. 2000;94 Suppl 1:S1-90.

8. Bottieau E, Clerinx J, Schrooten W, Van den Enden E, Wouters $R$, Van Esbroeck M, et al. Etiology and outcome of fever after a stay in the tropics. Arch Intern Med. 2006;166(15):1642-8.

9. Smith AD, Bradley DJ, Smith V, Blaze M, Behrens RH, Chiodini PL, et al. Imported malaria and high risk groups: observational study using UK surveillance data 1987-2006. BMJ. 2008;337:a120. doi: 10.1136/bmj.a120.

10. Legros F, Bouchaud O, Ancelle T, Arnaud A, Cojean S, Le Bras J, et al.. Risk factors for imported fatal Plasmodium falciparum malaria, France, 1996-2003. Emerg Infect Dis. 2007;13(6):883-8.

11. World Health Organization. World Malaria Report 2010. Geneva: WHO; 2010. Available from: http://www.who.int/ malaria/world_malaria_report_2010/worldmalariareport2010. pdf

12. World Health Organization Regional Office for Europe (WHO/Europe). European health for all database (HFA-DB). Copenhagen: WHO/Europe. [Accessed: 21 Jun 2012]. Available from: http://data.euro.who.int/hfadb/

13. Danis M. Pathologies du voyage ? Maladies mondiales réémergentes. [Travel illness? Global re-emerging diseases]. Bull. Epidemiol. Hebdo. 2011;18-19:205-6. [French]. Available from: http://www.invs.sante.fr/beh/2011/18_19/beh_18_19.pdf

14. Imported malaria cases by species and reason for travel, United Kingdom: 2007 to 2011. Data from the HPA malaria Reference Laboratory. London: Health Protectin Agency. [Accessed: 21 Jun 2012]. Available from: http://www.hpa.org.uk/Topics/InfectiousDiseases/ InfectionsAZ/Malaria/EpidemiologicalData/ malaEpizolmportedmalariacasesbyreason/

15. Armengaud A, Legros F, D’Ortenzio E, Quatresous I, Barre $\mathrm{H}$, Houze $\mathrm{S}$, et al. A case of autochthonous Plasmodium vivax malaria, Corsica, August 2006. Travel Med Infect Dis. 2008;6(1-2):36-40.

16. Santa-Olalla Peralta P, Vazquez-Torres MC, Latorre-Fandos E, Mairal-Claver P, Cortina-Solano P, Puy-Azón A, et al. First autochthonous malaria case due to Plasmodium vivax since eradication, Spain, October 2010. Euro Surveill. 2010;15(41): pii=19684. Available from: http://www. eurosurveillance.org/ViewArticle.aspx?Articleld=19684

17. Leder K, Tong S, Weld L, Kain KC, Wilder-Smith A, von Sonnenburg F, et al. Illness in travelers visiting friends and relatives: a review of the GeoSentinel Surveillance Network. Clin Infect Dis. 2006;43(9):1185-93.

18. Florescu SA, Popescu CP, Calistru P, Ceausu E, Nica M, Toderan $A$, et al. Plasmodium vivax malaria in a Romanian traveller returning from Greece, August 2011. Euro Surveill. 2011;16(35). pii=19954. Available from: http://www.eurosurveillance.org/ ViewArticle.aspx?Articleld $=19954$

19. Danis K, Baka A, Lenglet A, Van Bortel W, Terzaki I, Tseroni $M$, et al. Autochthonous Plasmodium vivax malaria in Greece, 2011. Euro Surveill. 2011;16(42):pii=19993. Available from: http://www.eurosurveillance.org/ViewArticle. aspx?Articleld=19993

20. Allwinn R. Significant increase in travel-associated dengue fever in Germany. Med Microbiol Immunol. 2011;200(3):155-9.

21. Vinner L, Domingo C, Ostby AC, Rosenberg K, Fomsgaard A. Cases of travel-acquired dengue fever in Denmark 2001-2009. Clin Microbiol Infect. 2012;18(2):171-6.

22. Thai KTD, Wismejer JA, van Vugt $M$, Wolthers, KC, de Vries PJ. Dengue fever among ill-returned travellers and concurrent infection by two dengue virus serotypes. Dengue Bulletin. 2009;33: 60-9. Available from: http://www.searo.who.int/ LinkFiles/Dengue_Bulletins_6-vol33.pdf

23. World Health Organization (WHO). Situation update of dengue in the SEA Region, 2010. The global situation of Dengue. Geneva: WHO. Available from: http://www.searo.who.int/ LinkFiles/Dengue_Dengue_update_SEA_2010.pdf

24. Pan American Health Organization (PAHO). Number of reported cases of dengue and figures for 2010 (to week noted by each country). Epidemiological Week / EW 52. Washington: PAHO. [Accessed: 21 Jun 2012]. Available from: http://new.paho.org/ hq/dmdocuments/2011/dengue_cases_2010_May_20.pdf

25. Gautret P, Botelho-Nevers E, Charrel RN, Parola P. Dengue virus infections in travellers returning from Benin to France, July-August 2010. Euro Surveill. 2010;15(36).pii=19657. Available from: http://www.eurosurveillance.org/ViewArticle. aspx?Articleld $=19657$

26. Gautret P, Simon F, Hervius Askling H, Bouchaud O, LeparcGoffart I, Ninove L, et al. Dengue type 3 virus infections in European travellers returning from the Comoros and Zanzibar, February-April 2010. Euro Surveill. 2010;15(15): pii=19541. Available from: http://www.eurosurveillance.org/ViewArticle. aspx?Articleld $=19541$

27. La Ruche G, Souarès $Y$, Armengaud A, Peloux-Petiot F, Delaunay $P$, Desprès $P$, et al. First two autochthonous dengue virus infections in metropolitan France, September 2010. Euro Surveill. 2010;15(39): pii=19676. Available from: http://www. eurosurveillance.org/ViewArticle.aspx?Articleld=19676

28. Grandadam M, Caro V, Plumet S, Thiberge JM, Souarès Y, Failloux $A B$, et al. Chikungunya virus, southeastern France. Emerg Infect Dis. 2011;17(5):910-3.

29. Rezza G, Nicoletti L, Angelini R, Romi R, Finarelli AC, Panning $M$, et al. Infection with Chikungunya virus in Italy: an outbreak in a temperate region. Lancet 2007;370(9602):1840-6.

30. Entente Interdépartementale pour la démoustication du littoral Méditerranéen (EID) Méditerranée. Enquête entomologique dans le cadre de la surveillance d'Aedes albopictus. [Interdepartmental agreement for mosquito control on the Mediterranean coast. Entomological survey in the context of Aedes albopictus surveillance]. Marseille (13) Compte-rendu d'intervention. Internal document. 5 Oct 2009. [French].

31. Bottieau E, Clerinx J, Vlieghe E, Van Esbroeck M, Jacobs J, Van Gompel A, et al. Epidemiology and outcome of Shigella, Salmonella and Campylobacter infections in travellers returning from the tropics with fever and diarrhoea. Acta Clin Belg. 2011;66(3):191-5.

32. Jean SS, Hsueh PR. High burden of antimicrobial resistance in Asia. Int J Antimicrob Agents. 2011;37(4):291-5.

33. Perez-Molina J, Perez-Ayala A, Parola P, Jackson Y, Odolini S, Lopez-Velez R, et al. EuroTravNet: imported Chagas disease in nine European countries, 2008 to 2009. Euro Surveill. 2011;16(37).pii=19966. Available from: http://www. eurosurveillance.org/ViewArticle.aspx?Articleld=19966

34. Marano C, Freedman DO. Global health surveillance and travelers' health. Curr Opin Infect Dis. 2009;22(5):423-9. 